\title{
Az energetikai audit európai uniós követelményei Németországban
}

\author{
energetikai audit - energiahatékonyság - nagyvállalatok - \\ Európai Unió - Németország
}

Az Európai Uniónak az energiahatékonyságról szóló 2012/27/EU irányelve (a továbbiakban: irányelv) arra kötelezi a tagállamokat, hogy 2015. december 5-éig biztosítsák valamennyi nagyvállalatnál ún. energetikai auditok (másként energiaauditok) elvégzését. ${ }^{1}$ A szabályozás hatálya alá tartozik minden olyan vállalat, amelyik nem esik a kis-, illetve középvállalkozások (a továbbiakban: kkv) kategóriájába. A tagállamoknak a vonatkozó előírásaikat - az irányelv transzpozícióra kitűzött határidejének megfelelően - 2014. június 5-ig kellett, illetve kellett volna meghozniuk. A német transzpozíció (csakúgy, mint a magyar) késedelmesen valósult meg (csak 2015 elején léphetett hatályba). Az előírásnak való megfelelés (amely Németországban csaknem 50000 vállalatot érint) komoly kihívásokkal jár; az alábbiakban ezek leküzdéséhez kívánok fogódzót nyújtani részben az uniós, részben a német szabályozás áttekintésével.

\section{Az uniós elöírások a 2012/27/EU irányelvben}

Az Európai Unió Működéséről szóló Szerződés új, 194. cikkében foglalt jogalapra hivatkozással - amely az EU energiapolitikájáról, illetőleg azon belül többek közt

* Dr. Jan Hoffmann, LL.M. Eur., igazgatóhelyettes, Brandenburgi Műszaki Egyetem, Jog- és Közigazgatástudományi Központ, Cottbus (Németország), jan.hoffmann@b-tu.de. The author thanks professor Fodor László very much indeed for translating the contribution into Hungarian.

Az energiahatékonysági irányelv föbb rendelkezéseit a folyóirat 2014/2. számában tekintettük át (63-87), anélkül azonban, hogy az auditálás részleteire is kitértünk volna. Jelen tanulmány hiánypótló jellegét erősíti, hogy a szerzőnek a témakört feldolgozó publikációi nemzetközi viszonylatban is a legelsők közé tartoznak. HoffMAnN, Jan: Obligatorische Energieaudits in „großen” Unternehmen - Zur Novelle des Energiedienstleistungsgesetzes (EDL-G). Compliance-Berater (CB), 2014/12, 454-459; Hoffmann, Jan: Die Verpflichtung zur Durchführung von Energieaudits gemäß §§ 8 ff. EDL-G 2015. Contracting und Recht (CuR), 2015/1, 4-9 (F. L.). Lásd még KRÜGER, Thomas-SABERZADEH, Leila: Gemeinnützige Organisationen als Adressaten der Energieauditpflicht nach § 8 EDL-G?, Zeitschrift für das Recht der Non Profit Organisationen (npoR), 2015/4, 245-248; Ehrsam, Uwe-ReInHARdt, Mario: Handlungsbedarf auch für kleine Unternehmen und öffentliche Betriebe? Die Wirtschaftsprüfung (WPg), 2015/22, 1184-1191; SCHADE, Christoph: Energieaudits nach dem Energiedienstleistungsgesetz. Contracting und Recht (CuR), 2015/3, 104-110; LENDERMANN, Marc: Der neue Rechtsrahmen für Energieaudits in Unternehmen. Zeitschrift für das gesamte Recht der Energiewirtschaft (EnWZ), 2015/7, 291-296. 
az energiahatékonyság ösztönzéséröl szól - fogadta el az Európai Parlament és a Tanács az energiahatékonysági irányelvet. ${ }^{2} \mathrm{E}$ jogszabály hivatása, hogy biztosítsa a jogi kereteket „...az energiahatékonyságnak az Unió egészében történő előmozdítására annak érdekében, hogy az Unió 2020-ig elérendő 20\%-os kiemelt energiahatékonysági célkitüzése teljesüljön..."3 8. cikkében kötelező előírásokat fogalmaz meg az ún. energetikai auditokról, amely előírásokat gyakran „papírtigrisnek” neveznek. ${ }^{4}$ Helyesebb azonban az energiahatékonysági szabályozás születendőben lévő részterületéről beszélni, ${ }^{5}$ amelynek a vállalatok életében egyre nagyobb lesz a jelentősége.

\subsection{Mi is az energetikai audit?}

Az energetikai audit fogalmát az uniós jogalkotó az irányelv 2. cikk 25) pontjában ekképp határozza meg: „...olyan szisztematikus [a magyar szöveg szerint: »meghatározott módszerrel végzett «] $]^{6}$ eljárás, amelynek célja megfelelő ismeretek gyüjtése valamely épület vagy épületcsoport, ipari vagy kereskedelmi müvelet vagy létesítmény, illetve magán- vagy közszolgáltatás aktuális energiafogyasztási profiljára vonatkozóan, továbbá amely meghatározza és számszerüsiti a költséghatékony energiamegtakarítási lehetőségeket, és egy jelentésben számol be az eredményekről”. [A magyar irányelvszövegben nem esik szó jelentésről.]

Az irányelv 8. cikk 4) bekezdése szerint olyan átvilágítást jelentenek ezek, amelyeket „képesített és/vagy akkreditált szakemberek végeznek független és költséghatékony [a magyar szöveg szerint csak független és hatékony!] módon, vagy amelyeket a nemzeti jogszabályoknak megfelelően független hatóságok hajtanak végre és felügyelnek".

2 Az Európai Parlament és a Tanács 2012/27/EU irányelve az energiahatékonyságról, a 2009/125/EK és a 2010/30/EU irányelv módosításáról, valamint a 2004/8/EK és a 2006/32/EK irányelv hatályon kívül helyezéséről (HL L 315, 2012. 11. 14., 1-56); módosította a Tanács 2013/12/EU irányelve (HL L 141, 2013. 05. 28., 28); Bizottsági iránymutatás az energiahatékonysági irányelv végrehajtásáról, $\operatorname{COM}(2013) 762$ végleges, 3-4. pont.

3 Lásd az irányelv 1. cikkének 1) bekezdését, illetőleg a 20\%-os célkitűzésre HoffmanN, Jan: „Living well, within the limits of our planet" - Das Siebte Europäische Umweltaktionsprogramm (2013-2020). Neue Zeitschrift für Verwaltungsrecht (NVwZ), 2013, 534; illetve az Európai Bizottság közleménye az energiahatékonyságról és annak hozzájárulásáról az energiabiztonsághoz és a 2030-as klíma-energiapolitikai keretek c. közleményét (2014. 07. 23.) COM(2014) 520 végleges.

4 Lásd (Nebelre hivatkozva) WeIDERMAnN, Sabine: Energieumweltrecht in Zeiten von Europäisierung und Energiewende. Europäisches Wirtschafts- und Steuerrecht (EWS), 2014/1, 36.

5 HärTEL, Ines: Energieeffizienzrecht - ein neues Rechtsgebiet? Natur und Recht (NuR), 2011, 825, 833; illetve már előtte is így foglalt állást Britz, Gabriele-Eifert, Martin-Reimer, Franz (Hrsg.): Energieeffizienzrecht. Nomos, Baden-Baden, 2010, 63, 107.

6 Az eredeti német tanulmányszöveg többször is idézi az irányelvet. Ezt a megoldást a fordítás során is megtartjuk, ugyanakkor szükségesnek látjuk a német és a - többnyire szakszerűtlen - magyar irányelvszöveg olyan eltéréseire rámutatni, amelyek tartalmi jelentőséggel bírnak. Elképzelhető, hogy a szerző által megfogalmazott gondolatok mögött másutt is a magyartól eltérő normaszöveg rejlik, de ennek a feltárását nem végezhetjük el. (F. L.) 
Az irányelv elvárásainak megfelelő auditról csak akkor beszélhetünk, ha az irányelv VI. sz. mellékletében felsorolt minimális kritériumok mindegyike teljesül:

a) az energiafogyasztással és a (villamos energiára vonatkozó) terhelési profilokkal kapcsolatos naprakész, mért és visszakövethető müveleti (üzemi) adatokra épül;

b) magában foglalja az épületek vagy épületcsoportok, ipari müveletek vagy létesítmények energiafogyasztási profiljának részletes felülvizsgálatát;

c) lehetőség szerint az életciklusköltségek elemzésére épül, nem pedig az egyszerü megtérülési időszakokra, annak érdekében, hogy figyelembe vegyék többek között a hosszú távú megtakarításokat, a hosszú távú beruházások maradványértékeit, valamint a diszkontrátákat;

d) arányos és megfelelően reprezentatív, annak érdekében, hogy megbízható képet adhasson az általános (össz)energiahatékonyságról, és segítségével megbízhatóan meg lehessen határozni a legjelentősebb javítási lehetőségeket.

Az energetikai auditoknak részletes és hitelesített számításokat kell lehetővé tenniük a javasolt intézkedésekre vonatkozóan annak érdekében, hogy világos tájékoztatást adjanak a potenciális megtakarításokról. A felhasznált adatokat a visszamenőleges elemzés és a teljesítmény nyomon követése érdekében meg kell őrizni.

\subsection{Az auditálásra kötelezett vállalatok köre}

Míg a kkv-szektorban a tagállamok feladata az auditok elvégzésére való ösztönzés, addig a kkv-szektorra irányadó küszöbértékeket ${ }^{7}$ meghaladó vállalatok esetén az auditok végrehajtatása kötelező [8. cikk 2) bekezdés, illetve 24) preambulumbekezdés]. Ennek első ízben 2015. december 5-ig, azt követően négyévenként kell megtörténnie.

Ez tulajdonképpen azt jelenti, hogy a nagyvállalatoknak (amelyek 249 fönél többet foglalkoztatnak, s éves árbevételük az 50 millió eurót meghaladja) máris energetikai auditot kell végeztetniük. Ez a kötelezettség független attól a körülménytöl, hogy az érintett vállalat az ún. energiaintenzív ágazatokhoz tartozik-e vagy sem. Míg az energiaintenzív szektor vállalatai ténylegesen már eddig is kötelesek voltak auditáltatni magukat, $s$ annak nyomán energiahatékonysági intézkedéseket megvalósítani (az energiaadóra, a megújuló energiából elóállított áram átvételére, illetve az elektromos áram adójára vonatkozó törvényi rendelkezések alapján), addig a többiek eddig mentesültek ezen elvárások alól. Az európai jogalkotó (eltérően például a pénzügyi kimutatásokról szóló 2013/34/EU irányelv módosítására vonatkozó európai bizottsági javaslattól) ${ }^{8}$ annak tudatában sem látott okot a foglalkoztatottak számára vonatkozó küszöbértéket felemelni (500 före), hogy a „kisebb nagyvállalatok”

A Bizottság 2003/361/EK sz. ajánlása a mikro-, kis- és középvállalkozások meghatározásáról, 36. (HL L 124, 2003. 05. 20., 36-41.)

8 Lásd az Európai Bizottságnak az irányelvjavaslatát a 78/660/EGK és a 83/349/EGK tanácsi irányelvnek a nem pénzügyi és a sokszínüséggel kapcsolatos információknak bizonyos nagyvállalatok és vállalatcsoportok általi közzététele tekintetében történő módosításáról, COM(2013) 207 végleges (2013. 04. 16.); illetve az Európai Parlament és a Tanács 2014/95/EU irányelvét (2014. október 22.) a 2013/34/EU irányelvnek a nem 
számára mekkora időigénnyel, illetve ráfordítással jár az energetikai auditok végrehajtása. Kiterjed még a kör a kisebb, de közösségi ellenőrzés alatt álló vállalatokra is, amelyekben az állam (illetőleg közjogi személy) legalább 25\%-ban tulajdonos vagy ilyen arányban irányítási jogokat gyakorol. Az ilyen „ellenőrzött” vállalatok - a foglalkoztatottak számától, az éves árbevételtől, illetve mérlegfőösszegtől függetlenül - a nagyvállalatokhoz sorolandók, ${ }^{9}$ ami Németországban az auditálásra kötelezett piaci szereplők körének jelentős bővülését eredményezi.

\subsection{Mentesítések}

Az irányelv 8. cikk 6) bekezdése lehetővé teszi az auditálási kötelezettség alóli mentesítést. „Azok a kkv-nek nem minősülő vállalkozások, amelyek egy független szerv által a vonatkozó európai vagy nemzetközi szabványoknak megfelelően tanúsitott energetikai vagy környezeti menedzsmentrendszert [másként környezeti irányítási rendszert; a magyar irányelvszöveg szerint környezetgazdálkodási rendszert] hajtanak végre, mentesülnek a (4) bekezdésben foglalt auditálási kötelezettség alól, feltéve, hogy a tagállamok biztosítják, hogy az érintett menedzsmentrendszer magában foglalja a VI. mellékletben foglalt minimumkövetelmények alapján végzett energetikai auditot."

\subsubsection{Energetikai menedzsment}

Az irányelv alapján a mentesítések körében a DIN EN ISO 50001 sz. nemzetközi szabványnak megfelelő energetikai audit jöhet szóba. ${ }^{10}$ Az ISO 50001-es szabvány célja a különböző méretű vállalkozásokat olyan helyzetbe hozni, hogy azok az energetikai teljesítményüket - ideértve az energiahatékonyságot, az energiafelvételt, illetve -fogyasztást - javító rendszereket, eljárásokat építhessenek ki. Az átfogó és szisztematikus energetikai menedzsmentnek - a mérés, dokumentáció, az energetikai teljesítményt befolyásoló létesítményekre, rendszerekre, eljárásokra, személyzetre vonatkozó tervezési és beszerzési gyakorlat (például energetikai megbízott alkalmazása) révén - csökkentenie kell az adott szervezet energiaköltségeit. Ennek érdekében az energetikai irányítási rendszerrel szemben olyan követelményeket rögzít a szabvány, amelyek révén az adott szervezet, illetve vállalat képessé válik saját energiapolitika megfogalmazására, stratégiai, illetve operatív energetikai célok kitűzésére, illetve az ezek eléréséhez szükséges programok megvalósítására. A szabvány energia alatt egyaránt érti az elektromos energiát, a tüzelőanyagokat, a hőt, a sűrített levegőt stb. A szabvány szerinti tanúsítvány elnyeréséhez nem szük-

pénzügyi és a sokszínüséggel kapcsolatos információknak bizonyos nagyvállalkozások és vállalatcsoportok általi közzététele tekintetében történő módosításáról. (HL L 330, 2014. 11. 15., 1-9.)

9 Lásd a Bizottság már hivatkozott 2003/361/EK sz. ajánlásának mellékletét; 3. cikk 4) pont.

10 Energiemanagementsysteme in der Praxis - ISO 50001: Leitfaden für Unternehmen und Organisationen. BMU - UBA (Hrsg.), Berlin-Dessau, 2012. https://www.umweltbundesamt.de/sites/default/files/medien/ publikation/long/3959.pdf (2016. 02. 19.). [A szabványra magyarul lásd http://www.mszt.hu/web/guest/mszen-iso-50001 - F. L.] 
séges egy meghatározott energetikai teljesítmény elérése. Az ISO-szabványok átfedéseire, összekapcsolódására tekintettel az adott vállalat úgy is dönthet, hogy nem külön energetikai menedzsmentet vezet be, hanem azt integrálja, például a környezetirányítási rendszerébe.

\subsubsection{Környezetirányítási rendszerek}

A környezeti menedzsmentrendszerek hatóköre tágabb az energetikai irányítási rendszerekénél. Míg az energetikai menedzsment környezeti szempontból csak az energiahatékonyságot, illetve az üvegházhatású gázok kibocsátásának csökkentését s az ezekkel összefüggő egyéb környezeti hatások csökkentését célozza, addig egy környezetirányítási rendszer a környezetvédelem valamennyi részterületét egységesen átfogja. ${ }^{11}$ Az Európai Unió saját környezetirányítási rendszere az EMAS („az Európai Unió környezetvédelmi vezetési és hitelesítési rendszere”), amely jelentős mértékben támaszkodik a DIN EN ISO 14001-es szabványra, de szigorúbb követelményeket támaszt annál. ${ }^{12} \mathrm{Az}$ EMAS célkitüzése, hogy elösegítse az érintett szervezetek, vállalatok környezeti teljesítményének a folyamatos javulását. Ebben a rendszerben a részvétel önkéntes; a résztvevők felállítják környezeti irányítási rendszerüket, s annak teljesítményét időszakosan objektív auditálásnak vetik alá, elöre rögzített szempontok szerint. A környezeti teljesítményükröl nyert információkat megosztják a nyilvánossággal, illetöleg a különböző érdekeltekkel. A rendszerben a szervezet munkavállalói is aktívan részt vesznek, illetve az ő ismereteiket is fejlesztik.

Az irányelv mindkét (tehát az ISO 14001-es szabvány és az EMAS szerinti) ${ }^{13}$ környezeti irányítási rendszer esetére mentesítést biztosít, amennyiben részüket képezi az energetikai audit is. Ez a feltétel az EMAS esetén mindenképpen teljesül, hiszen az a vonatkozó rendelet szerint az energiafelhasználásra is kiterjed, illetve az energiahatékonyság az EMAS egyik legfontosabb indikátora. Ezzel szemben az ISO 14001-es szabvány csupán a lényegesebb környezeti szempontoknak a beazonosítását követeli meg az adott vállalatnál, s speciális kritériumok erre nincsenek elóírva. ${ }^{14} \mathrm{Az}$ energiafogyasztás ennek az irányítási rendszernek is tárgya lehet, de nem feltétlenül az, ezért a mentesítésre csak egyedi elbírálás alapján kerülhet sor.

11 Guidance note on Directive 2012/27/EU on energy efficiency, amending Directives 2009/125/EC and 2010/30/EC, and repealing Directives 2004/8/EC and 2006/32/EC. Article 8: Energy audits and energy management systems. SWD(2013) 447 végleges, 13.

12 Lásd az Európai Parlament és a Tanács 1221/2009/EK rendeletét a szervezeteknek a közösségi környezetvédelmi vezetési és hitelesítési rendszerben (EMAS) való önkéntes részvételéröl és a 761/2001/EK rendelet, a 2001/681/EK és a 2006/193/EK bizottsági határozat hatályon kívül helyezéséröl (HL L 342, 2009. 12. 22., 1-45.), a szabványt illetően pedig az ISO hivatalos oldalát: http://www.iso.org/iso/home/standards/ management-standards/iso14000.htm (2016. 02. 19.).

13 A két rendszer németországi elterjedésére vonatkozóan lásd HofFmanN, Jan: Umweltmanagementsysteme waren gestern? - Zur Verbreitung von EMAS und der ISO-Norm 14001 in Deutschland. Zeitschrift für Umweltrecht (ZUR), 2014/2, 81.

14 Energiemanagementsysteme in der Praxis... i. m., 87, 92. 


\subsection{Energetikai auditok - DIN EN 16247-1}

Amennyiben az irányelv szerint kötelezett vállalatnak sem energetikai, sem környezetközpontú irányítási rendszeréröl nincs tanúsítványa, akkor az irányelv szerinti auditra van szüksége. Az irányelv mellett az energetikai auditra vonatkozóan a DIN EN 16247-1 európai szabvány tartalmaz olyan elöírásokat, amelyeket az európai jogalkotó szándéka szerint figyelembe kell venni. A szabvány általános elvárásokat rögzít az audit módszerére, eredményeire vonatkozóan. Energetikai audit alatt egy adott szervezet energiabevitelének és -felhasználásának módszeres vizsgálatát és elemzését érti, amelynek célja az energiaáramlási folyamatok és az energiahatékonyság javítása terén mutatkozó lehetőségek meghatározása, azokról jelentés készítése. Mivel az audit eszerint, az előző pontban említett energetikai, illetve környezeti irányítási rendszerekkel ellentétben, amelyek folyamatosan értékelik az adott szervezet teljesítményét, csupán egy adott időpontban jellemző állapot megragadására alkalmas, az irányelv annak rendszeres (négyévenkénti) elvégzését várja el.

\section{A németországi transzpozíció}

\subsection{Elözmények}

Mint említettem, az energiahatékonysági irányelv németországi átültetése nem történt meg az erre biztosított határidőn belül. A késedelem oka az volt, hogy a szövetségi gazdasági minisztérium az átültetésben elöbb nem annyira esélyt, mint inkább veszélyt látott a német gazdaság szempontjából. ${ }^{15}$ Új miniszter kellett ahhoz, hogy érdemben elkezdjenek foglalkozni az irányelv átültetésével, elkészüljenek a megalapozó tanulmányok, de mindez a transzpozíciós határidőn belül már nem vezethetett eredményre.

Emiatt 2014 júliusában az Európai Bizottság kötelezettségszegési eljárást indított, amely innentől kezdve Damoklesz kardjaként árnyékolta be a jogalkotás folyamatát. A gazdasági minisztérium rövid időn belül közzétett egy szabályozási koncepciót, amely azonban rögtön a különböző vállalati érdekképviseletek célkeresztjébe került. Csak 2014 novemberére készült el egy a részleges átültetést célzó törvény tervezete, amelyet a szövetségi törvényhozás két háza - a gazdasági és energetikai bizottságok, illetve szakértők bevonása mellett - sürgősséggel tárgyalt, s végül 2015 tavaszán nyerte el végső formáját. ${ }^{16} \mathrm{~A}$ szövetségi tanács egyébként (a gazdasági bizottság javaslatára) egy külön határozatot is megszavazott a törvényhez kapcsolódóan, amelyben amellett foglalt állást, hogy a végrehajtás során törekedni kell majd az érintett vállalkozások terheinek a lehető legalacsonyabb szinten tartására. Az

15 DeHmer, Dagmar: Energieeffizienz. Nur warme Worte. Der Tagesspiegel, 2014. 08. 10., http://www.tagesspiegel.de/politik/energieeffizienz-nur-warme-worte/10314422.html (2016. 02. 20.).

16 Az energiahatékonysági irányelv részleges átültetéséröl és a versenykorlátozásokról szóló törvény $47 \mathrm{~g}$ §-a hatályon kívül helyezésének elhalasztásáról szóló, 2015. 04. 15-ei törvény, BGBI. 2015 I, 578; illetve annak tervezete: BT-Drs. 18/3373 (2014. 12. 1.). 
elfogadása másnapján (2015. április 22-én) hatályba lépö törvénynek az energetikai auditok szempontjából releváns rendelkezése az, amelyik az energetikai szolgáltatásokról szóló törvényt (EDL-G) ${ }^{17}$ módosította.

\subsection{Az irányelv részleges átültetéséröl szóló törvény}

Az irányelv részleges transzpozícióját megvalósító jogszabály egy ún. becikkelyező törvény, amelynek az 1. cikke rendelkezik az energetikai szolgáltatásokról szóló törvény módosításáról. Ebben az EDL-G 8-8d cikkeit egészítették ki az energetikai audit elvégzésének a kötelezettségével. Kötelezettként azok a nagyobb vállalatok szerepelnek, amelyek a kkv-ra vonatkozó, uniós előírásokban rögzített küszöbértékeket meghaladják. A törvényszöveg hivatkozik az elérendő uniós energiahatékonysági célkitűzésekre is, s egyúttal módosítja az energia-nagykereskedők piacfelügyeletére vonatkozó elöírásokat.

\subsubsection{Az auditálási kötelezettség}

A törvény 8 . $§(1)$ bekezdése az auditálási kötelezettség föbb elemeit rögzíti, kitérve a DIN EN 16247-1 szabványnak való megfelelésre, az audit tartalmára (energiaprofil, életciklus-elemzés, reprezentativitás és arányosság), a szakértőre, a vizsgálat függetlenségére egyaránt. Arra azonban nem állapít meg kötelezettséget, hogy az auditált vállalat ténylegesen javítsa is az energiahatékonysági teljesítményét. Az audit tehát csupán tükröt tart a vállalat elé. Így, jóllehet elvégzésének kötelezettsége a közvetlen magatartásszabályozás módszeréhez sorolható, valójában közvetlen szabályozás valósul meg, amelynek a fő eszköze az információ. ${ }^{18}$ Ezen keresztül igyekszik a jogalkotó mobilizálni a vállalatok környezeti érzékenységét, $s$ rávezetni őket az energiahatékonysági intézkedések megtételére. A nemzeti energiahatékonysági cselekvési tervet idézve a szabályozás mottója: „Az érintettek felelőssége az energiahatékonyság terén: mérni, megérteni, cselekedni, megtakarítani."’99

\subsubsection{Mentesitési tényállások}

Az EDL-G 8. § (3) bekezdése az irányelv rendelkezéseinek megfelelően mentesíti azokat a vállalatokat az auditálási kötelezettség alól, amelyek 2015. december 5-ig a DIN EN ISO 50001-es szabvány szerinti energetikai menedzsmentrendszert vagy az EMAS-rendeletben leírt környezetmenedzsment-rendszert vezettek be. Nem biz-

17 Az energetikai szolgáltatásokról és egyéb energiahatékonysági intézkedésekről szóló 2010. 11. 4-ei törvény (Energiedienstleistungsgesetz, röviden EDL-G), BGBI I 1483.

18 A környezetjog eszköztárára vonatkozóan lásd különösen KLoEPFER, Michael: Umweltrecht. C. H. Beck, München, 2004 (3. kiadás) 5. § D-E. pont; kifejezetten az energiahatékonysággal összefüggésben pedig JESSE, Sven: Instrumentenverbund als Rechtsproblem am Beispiel effizienter Energienutzung. Mohr Siebeck, Tübingen, 2014, 78.

19 https://www.bmwi.de/BMWi/Redaktion/PDF/M-O/nationaler-aktionsplan-energieeffizienz-nape,property =pdf, bereich=bmwi2012,sprache=de,rwb=true.pdf (2016. 02. 21.). 
tosít azonban felmentést azoknak, amelyek a DIN EN ISO 14001-es szabványnak megfelelő tanúsítvánnyal rendelkeznek. Ez annak ellenére így van, hogy a gazdasági érdekképviseletek szerették volna elérni ezt a mentesítést is, hivatkozva arra, hogy 2014-ben az ISO 14001-es szabványt jelentősen átdolgozták, többek közt nagyobb teret biztosítva abban a nyilvánosságnak, illetve a környezeti teljesítmény folyamatos javulásának. A jogalkotó azt vette ugyanis figyelembe, hogy a szabvány továbbra sem tartalmaz kötelező elemeket az energiahatékonyság terén. (Akinek tehát csak ISO 14001-es tanúsítványa van, annak egy a törvényben leírt energetikai auditot kell elvégeztetnie, vagy környezeti irányítási rendszerébe beépíteni az ISO 50001 szabvány szerinti auditot.) További mentesítéseket a törvény (más, energiahatékonysági előírásokkal, illetve egyes gazdasági szereplők követelésével szemben) nem tesz lehetővé.

\subsubsection{Kedvezmények a bevezetés időszakában (2015-2016)}

A törvény elfogadásának utolsó fázisában úgy döntött a jogalkotó, hogy az irányelv késedelmes végrehajtásának terhét, az időhiányt, nem hárítja át a gazdasági szereplökre ${ }^{20}$ ami egyfelöl (a) átmeneti rendelkezésekben, másfelöl (b) a törvényhozási eljárás folyamatában öltött testet.

a) Az utolsó pillanatban módosult úgy (az illetékes gazdasági és energetikai bizottság javaslatára) a törvényjavaslat szövege, hogy elég, ha az érintett vállalatok az energetikai audit elvégzése helyett a már említett környezeti vagy energetikai menedzsment alkalmazásáról döntenek, s ekképp haladékot kapnak. A 8. § 6) bekezdés c) pontja szerint 2015. december 5. és 2016. december 31. között elfogadják a kötelezettség teljesítéseként az adott vállalat vezetésének nyilatkozatát arra vonatkozóan, hogy megkezdte az előírásoknak megfelelő irányítási rendszer bevezetését.

Ezt a rendelkezést mind környezet-, mind gazdaságpolitikai szempontból üdvözölte a szakma. ${ }^{21}$ Mindkét menedzsmentrendszer túllép ugyanis az energiatakarékossági lehetőségek feltárásán, s a környezeti, illetve energetikai teljesítmény folyamatos, tényleges javítását követeli meg.

Kétséges ugyanakkor, hogy ez a haladék vajon nem jelent-e (további) kötelezettségszegést az irányelv tagállami transzpozíciója során. Az irányelv 8. cikk 4) bekezdése ugyanis 2015. december 5-éig az energetikai auditok első lefolytatását várja el a tagállamokban. Az irányelv szövege nem enged teret az olyan értelmezésnek, miszerint elegendő lenne eddigre megkezdeni az auditálást vagy az azt magában foglaló rendszer bevezetését. Egyértelművé teszi ezt a bizottsági iránymutatás is, amelyikben a határidő előtt még a „legkésőbb” kitétel is szerepel. ${ }^{22}$ Jóllehet, az iránymutatás csupán a Bizottság álláspontját tükrözi, a folyamatban lévő kötelezettségszegési eljárás során hivatkozási alap lehet, amennyiben megerősíti az - álláspontom szerint amúgy is egyértelmü - irányelvi intenciót.

20 Lásd az egyik képviselő felszólalását; BT-Plenarprotokoll 18/85, 2015. 02. 5., 8070 (D).

21 Így például a szövetségi környezetvédelmi hivatal (UBA), a környezeti menedzsmentrendszerek kívánatos terjedése szempontjából. Pressemitteilung Nr. 7/2015, 2015. 12. 13.

22 Guidance note on Directive 2012/27/EU..., 8. (27. p.). 
Ellenérvként lehet azonban hivatkozni az irányelv 8. cikk 6) bekezdésére, amelyik a mentesítés feltételeként - jelen időben - azt határozza meg, hogy az érintett vállalatok megfelelő menedzsmentrendszert „állítanak fel”. A Bizottság türelmére lehet számítani azért is, mert az átmeneti idő viszonylag rövid, s mert végeredményben az érintett vállalatok több kötelezettséget vállalnak magukra nézve, mint ami az irányelvi rendelkezésekböl feltétlenül következik. Az sem mellékes, hogy vélhetőleg növekedni fog az EMAS népszerüsége (ami nyilvánvaló érdeke az EU-nak), amelyet egyébként az a veszély fenyeget, hogy a jelentéktelenség homályába vész. ${ }^{23}$

b) A jogalkotás folyamán az érintett gazdasági szereplők kívánságait - az irányelvben több helyen is szereplő arányosság, reprezentativitás és költséghatékonyság követelményeire való hivatkozással - nagymértékben figyelembe vették. Kulcsszóvá vált a belső energetikai audit (a külsővel szemben), az amortizációs ciklus (az életciklussal szemben), illetve a mintavételszerü vizsgálat (Multi-Site-Verfahren) a több telephellyel rendelkező vállalatok számára (valamennyi telephely átfogó értékelése helyett).

A 2015 januárjában lefolytatott szakértői konzultáció felszínre hozta a gazdasági érdekképviseletek korábbi kritikáit, s újabb érdekek is megjelentek. Az egyes kívánságoknak a jogalkotó messzemenően meg kívánt felelni, de már a törvényszövegen kívül, egy határozat elfogadásával, amely a szövetségi kormány számára hivatott instrukciókat adni a törvény végrehajtására nézve. ${ }^{24}$

Sem a szakértői konzultáción elhangzottak, sem pedig az annak nyomán elfogadott határozat nem bír azonban kötelező erővel, vagyis nem járul hozzá a jogbiztonsághoz az érintett vállalatok szempontjából. Míg például egy törvénytervezet indokolásáról általánosan elfogadott, hogy az legalább a törvényszöveg értelmezése során felhasználható, addig jelen esetben még ez is kétséges. A szövetségi tanács ügyrendjének 75. § 2) bekezdése szerint a törvénytervezetekhez kapcsolódó határozati javaslatok nem önálló vitatárgyak; ezekről (a 88. § szerint) a törvényjavaslatokkal egyidejüleg szavaznak. Ezek a dokumentumok rendszerint a kormánynak szóló kérések, s (csak) a szövetségi tanács álláspontját fejezik ki. Ezekhez a szövetségi kormány nincs kötve, tartalmukra az érintett vállalatok nem is hivatkozhatnak (jogi eljárásokban). ${ }^{25}$

Azt, hogy mégis miért ezt a megoldást választotta a jogalkotó, az indokolhatja, hogy nem kívánt - magában a törvényszövegben - muníciót adni az Európai Bizottság számára, amit az a kötelezettségszegési eljárásban felhasználhatna, hanem ehelyett bízik a törvény „csendes végrehajtásában”. ${ }^{26}$

23 Hoffmann: Umweltmanagementsysteme... i. m., 81.

24 BT-Drs. 18/3934, 2015. 02. 4, 3.

25 Lásd a német szövetségi parlament ügyrendjét, 1980. 06. 25., (BGBI. 1980 I, 1237), amelyet legutóbb 2014. 03. 04-én módosítottak; illetve RoLl, Hans-Achim: Kommentar zur Geschäftsordnung des deutschen Bundestags. Nomos, Baden-Baden, 2001, az ügyrend 88. §-áról szóló alfejezet 3. pontját.

26 A törvényhozó ehhez egy kiskaput nyitva hagyott, a kormány számára adott, végrehajtási rendelet kiadására vonatkozó felhatalmazással. BT-Drs. 18/3934, 4. Ezenfelül lásd a szövetségi gazdasági és exportellenőrzési hivatal (BAFA) prospektusát, amely 2015 áprilisa óta a hivatal honlapjáról letölthető. http://www.bafa.de/ bafa/de/energie/energie_audit/publikationen/merkblatt_energieaudits.pdf (2016. 02. 21.). 


\subsection{Kell-e tartani a Bizottság kifogásaitól a végrehajtás módját illetően?}

\subsubsection{Mintavételszerü vizsgálat (Multi-Site-Verfahren)}

Különösen a német kereskedelmi szövetség érvényesítette azt az álláspontot, hogy a vállalatoknak ne kelljen minden egyes fióktelepüket auditáltatniuk, hanem ehelyett egyetlen közös vizsgálatra kerülhessen sor, a vállalat által meghatározott sztenderdeket érvényesítö telephelyek esetében. Ezt a megoldást az ISO 50001-es szabvány is ismeri. Mellette szóló érvként a kereskedelmi szövetség az irányelv értelmére, illetöleg a felesleges költségek elkerülésére hivatkozott, ${ }^{27} \mathrm{~s}$ ezek jegyében szerette volna módosíttatni, illetve kiegészíttetni a törvény szövegét.

Ebben az értelemben foglalt állást a CDU/CSU, illetve az SPD-frakció is: a szövetségi tanács elvárja a kormánytól, hogy az EDL-G végrehajtása során úgy alkalmazza a törvény 8a §-ának (1) bekezdését, hogy a nagyszámú, hasonló telephellyel rendelkező vállalatok esetében az auditálási kötelezettség arányossága és reprezentativitása azzal teljesül, ha az audit az energetikai menedzsmentrendszerekben végzett tanúsításnak megfelelő módon történik. Ennek érdekében a német akkreditációs testület (Deutsche Akkreditierungsstelle $\mathrm{GmbH}$ ) 71 SD 6022. sz. szabályzatának 9.1.5. pontjában foglalt mintavizsgálat folytatható le, ahol a hasonló fogyasztási profillal rendelkező telephelyek klasztereket képeznek. Az említett frakciók a szövetségi gazdasági és exportellenőrzési hivataltól megfelelő alkalmazási segédlet kidolgozását kérték.

A német akkreditációs testület említett szabálya a nemzetközi akkreditációs fórum (International Accreditation Forum) mindenkor hatályos IAF MD 1 sz. elóírására hivatkozik, amely a környezeti - illetve energetikai - menedzsmentre is értelemszerűen irányadó. Eszerint az auditálást végző szervezetnek vizsgálnia és dokumentálnia kell, hogy fennállnak-e a mintavizsgálat elöfeltételei. Az audit során vizsgálandó (minta)telephelyet/telephelyeket a tanúsítványt kiállító szervezet és a vezető auditáló szakember együtt választja ki; az annak nyomán kiadott tanúsítvány pedig az adott vállalat valamennyi telephelyére kiterjed.

Az irányelvben, illetve a kapcsolódó bizottsági iránymutatásban hiába keresnénk a mintavizsgálat lehetöségére való utalást. Persze az irányelvnek a költséghatékonyságra, arányosságra és reprezentativitásra vonatkozó követelményei tükrében védhető az az álláspont, amely szerint az, ami az energetikai menedzsmentrendszerben jogszerü, annak az energetikai auditálás során is megengedettnek kell lennie. De hogy miként áll e kérdéshez az Európai Bizottság, egyelőre nem ismert. Ha az irányelvvel ellentétesnek tartaná, akkor ezt a német hatóságoknak is figyelembe kell venniük a végrehajtás során. Úgy vélem, hogy még nem hangzott el az utolsó szó ebben az ügyben.

${ }_{27}$ BT-Drs. 18/3934, 5. (II/1. pont), illetve lásd a szövetségi tanács határozatát, BR-Drs. 47/1/15, 2. 


\subsubsection{Amortizációs ciklus kontra életciklus}

Egyes vállalatok kifogásolták azt a „minimális követelményt” is, amely szerint az auditálásnak lehetőség szerint a teljes életciklusra, s nem csupán az amortizációs időszakra kiterjedő költségelemzésen kell alapulnia, annak érdekében, hogy az audit a hosszú távú megtakarítási lehetőségeket is feltárhassa. Ennek az elöírásnak a fontossága elsőrendü, tekintve, hogy energiahatékonysági beruházásairól a német vállalatok közel $85 \%$-a a befektetés kockázatai alapján hoz döntést, és azt jelenti, hogy a megtérülési időszak többnyire nem lehet hosszabb 2-3 évnél. (Ez a hozzáállás persze igazából azon vállalatok esetén racionális, amelyek 3-4 évre elöre be tudják állítani a termelésüket.) Ezzel szemben a 10-15 év alatt megtérülő beruházások - új hőtermelő berendezések, ventilátorok, hulladékhő hasznosítók stb. - esetén ezen energiatakarékossági lehetőségeknek az elvetése a kifizetődőbb. ${ }^{28}$

A szövetségi törvényhozás a törvényhez kapcsolt határozatában azt kéri a kormánytól, hogy a törvény $8 a$ § (1) bekezdésének a végrehajtása során az életciklus-elemzéssel egyenértékűnek fogadja el az értékcsökkenési időszakon alapuló elemzéseket azokban az esetekben, amelyekben az életciklus-elemzés aránytalan többletteherrel járna, illetőleg a gyártó nem rendelkezik megfelelő adatokkal a megtérülésről. Úgy vélem, ez a megközelítés aggálymentesen képviselhető, hiszen az irányelv a teljes életciklus figyelembevételét a tényleges megvalósíthatóság, illetve az arányosság kikötésével írja elö. (A parlament egyébként ebben a tekintetben is felhívta a szövetségi gazdasági és exportellenőrzési hivatalt megfelelő útmutató készítésére.)

\section{Következtetések és kitekintés}

Összességében elmondható, hogy a parlament igyekezett minél nagyobb mértékben figyelembe venni a gazdasági érdekképviseletek követeléseit a transzpozíció során. Amennyiben ez nem magában a törvényszövegben történt, az érdekelt vállalatok számára jogi garanciát nem biztosít. Emellett problematikusnak tekinthetők a törvényszöveg utolsó pillanatban felvett módosításai is, amennyiben kérdéses az EU-jognak való megfelelésük.

$A z$, hogy a szövetségi gazdasági minisztérium hogyan fog élni a rendeletalkotásra vonatkozó felhatalmazással (EDL-G 8d §) a törvény végrehajtása során - az audit részleteit, az auditálást végző szakértők személyét vagy a mentesítéseket illetően -, egyelöre nem látható. Ugyanez a helyzet azzal a kérdéssel, hogy (a határidőre is tekintettel) vajon lesz-e elég szakember, aki az auditálást végezheti. $E$ tekintetben a szövetségi gazdasági és exportellenőrzési hivatal segédlete áll rendelkezésre, amely tartalmazza a 2015 márciusa óta nyilvántartásba vett olyan személyek nevét, akik az ehhez megfelelő szakértelemmel rendelkeznek. (Azt, hogy milyen feltételekkel lehet felkerülni erre a listára, szintén ennek a hivatalnak az útmutatója részletezi.)

28 Jochem, Eberhard-Lösch, Oliver-MAI, Michael-Mielicke, Ursula-ReITZE, Felix: Energieeffizienz in der deutschen Industrie - brachliegende Chancen. Energiewirtschaftliche Tagesfragen (et), 2014/1-2, 81, 83. 
Az irányelv maximális implementációjára irányuló ellenzéki követeléseknek amelyek az auditálási kötelezettséget a kkv körére is kiterjesztenék - jelenleg nincs realitása, noha az irányelv erre kifejezetten bátorítja a tagállamokat. Pártok feletti a konszenzus viszont abban a tekintetben, hogy az energetikai audit csupán köztes lépés a nagyobb energiahatékonyság felé vezető úton. A puszta energetikai audit helyett célravezetöbb az energetikai irányítási rendszerek, de még inkább - az energiahatékonyságra is kiterjedő - környezetközpontú irányítási rendszerek alkalmazása. Ennyiben a törvényhozó által biztosított átmeneti időszak kifejezetten üdvözlendő. Ehhez járul, hogy számos vállalat (amely ma még „csak” energetikai audit elvégeztetésére köteles) 2017/18-tól - a nem pénzügyi jelentésekröl szóló irányelv 2014-es módosítása nyomán - helyzetjelentéseiben már köteles lesz megjeleníteni a környezeti szempontokat is. A környezeti menedzsmentrendszerek kiépítése ehhez a legmegfelelöbb kiindulási alapot képezheti. ${ }^{29}$

A legeslegjobb persze az lenne, ha - visszanyúlva az egész klíma-, illetve energiapolitikai szabályozás filozófiájáig - takarékosabban bánnánk a fosszilis energiahordozókkal, és a vállalatok klímasemleges energiaellátási rendszerekre állnának át. A piac már ma is biztosítja az ehhez szükséges energetikai szolgáltatásokat. A nem pénzügyi jelentésekröl szóló irányelv 7. preambulumbekezdése szerint is „[a] mennyiben a vállalkozások kötelesek nem pénzügyi kimutatást készíteni, a kimutatásnak a környezetvédelmi kérdések vonatkozásában tartalmaznia kell a vállalkozások környezetre [...] kiható müveleteinek aktuális és elöre látható hatásaival, a megújuló és/vagy a nem megújuló energiaforrások használatával, az üvegházgázkibocsátással, a vízhasználattal és a légszennyezéssel kapcsolatos részleteket."

Ami a Németországi Szövetségi Köztársaság ellen indított kötelezettségszegési eljárást illeti, a továbbiakban megfelelö körültekintésre van szükség. Azt, hogy a Bizottság komolyan veszi az irányelv transzpozíciójára vonatkozó tagállami kötelezettséget, mutatja a Magyarország ellen indított eljárás, amelyben napi 15444 euró kényszerítő bírság kiszabását kérte a nem megfelelő átültetés miatt. ${ }^{30} \mathrm{~A}$ Bizottság adatai szerint egyébként határidőre a huszonnyolcból mindössze négy tagállam (Ciprus, Olaszország, Málta és Svédország) teljesítette teljes körüen az irányelv átültetésére vonatkozó kötelezettségét.

2016 januárjától immár az EDL-G hatékony tagállami végrehajtásának a kérdése merül fel, ami alapvetően a már említett gazdasági és exportellenőrzési hivatal feladata. E tekintetben figyelemre méltó a hivatal számára biztosított, 50000 euróig terjedő bírságolási lehetőség.

(Fordította: Fodor László)

29 Lásd a már említett 2014/95/EU irányelvet, HL L 330. 2014. 11. 15., 1-9., illetve HoffmanN, Jan: Umweltbelange im Lagebericht nach § 289 HGB. Zeitschrift für Gesellschafts- und Wirtschaftsrecht (GWR), 2013/22, 458-462.

30 Lásd a Bizottság IP/15/4668. sz. sajtóközleményét, 2015. 03. 26. 


\section{Abstract}

The Energy Efficiency Directive (EED) No. 2012/27/EU establishes a set of binding measures to help the EU to reach its 20\% energy efficiency target by 2020 . Energy audits are an essential tool to achieve adequate energy savings (see art. 8. EED). The current study focuses on the EU legal requirement on Energy Audits and its implementation in Germany by the 2015 amended Act on Energy Services and other Energy Efficiency Measures (Gesetz über Energiedienstleistungen und andere Energieeffizienzmaßnahmen - EDL-G). The analysis is still relevant because of the infringement proceedings against Germany by the European Commission based on fragmentary transposition of the EED. 